\title{
Information Literacy Skills of Humanities, Arts, and Social Science Tertiary Students in Singapore
}

\author{
Schubert Foo, Xue Zhang, \\ Yun-Ke Chang, Shaheen Majid, \\ Intan Azura Mokhtar, Joanna \\ Sin, and Yin-Leng Theng
}

Schubert Foo(sfoo@pmail.ntu.edu. sg) is Professor; Xue Zhang was a PhD Candidate; Yun-Ke Chang and Joanna Sin are Assistant Professors; Shaheen Majid and Yin-Leng Theng are Associate Professors at the Division of Information Studies, Wee Kim Wee School of Communication and Information, Nanyang Technological University, Singapore.

\section{Intan Azura Mokhtar is Assistant} Professor at the Department of Policy and Leadership Studies, National Institute of Education, Singapore.
Reference \& User Services Quarterly, vol. 53, no. 1, pp. 40-50 (c) 2013 American Library Association. All rights reserved.

Permission granted to reproduce for nonprofit, educational use.
Measuring and assessing information literacy (IL) competencies is essential to understand its educational impact as well as to explore pedagogies to improve it. This study is the first to acquire knowledge about Singapore tertiary students' skills in searching, evaluating, and using information. A total of 534 students from the College of Humanities, Arts, and Social Sciences, Nanyang Technological University, Singapore participated in this study through an online survey. Moderate IL skills scores of the respondents showed room for improvement especially in higherlevel skills related to information use, synthesis, and evaluation. Students receiving pretertiary education in Singapore scored higher than those from overseas did, which, to some extent, showed that IL education in Singapore is still more effective than that in some other countries. The IL course offered in the university was found to be useful and to lead to higher IL assessment scores.

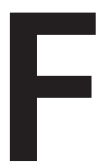
rom as far back as the 1980s, scholars and experts have endorsed the importance of and need for information literacy (IL) to deal with the exponentially increasing amounts of information that an individual is faced with everyday. ${ }^{1}$ The mission to equip future generations of students with IL was of such prime importance, that educational reforms and the increased role of the school library in the school curriculum were widely proposed and implemented across schools. ${ }^{2}$

In practice, IL is being taught either as an independent course or integrated into the other curricula. Some studies advocate the integration of IL skills across curricula to allow application of the skills in real situations. ${ }^{3}$ Examples of this could be found in South Africa, Canada, and the United States. ${ }^{4}$

IL education in Singapore dates back to the late 1990s when a series of guidelines and supplementary materials were published by the Ministry of Education (MOE) to assist IL instruction from the elementary to pretertiary level. ${ }^{5}$ Nonetheless, the emphasis on IL education lost momentum with the closure of the Schools' Library Unit at MOE. IL education and school media resource libraries were left languishing for a few years. The libraries were managed by teachers, who lacked library and information science (LIS) skills and knowledge of co-curricular activity in schools. Subsequently, these libraries were outsourced to a commercial library vendor to manage clusters of school libraries to date. Recently, the MOE included "Information and Communication Skills" as one of the twenty-first-century competencies for students, which should lead to a revival of interest in IL education. ${ }^{6}$ In terms of 
IL education at tertiary education level, in 2008 the Wee Kim Wee School of Communication and Information, Nanyang Technological University, started to offer a compulsory course "Information Literacy and Interpretation" for enhancing its own undergraduates' skills for identifying, searching, locating, and evaluating information.

Measuring and assessing IL competencies is essential to understand their educational impact as well as to explore pedagogies to improve them. Despite years of IL education in Singapore, no large-scale assessment has been conducted to find out students' levels of IL skills, in particular, for tertiary students. So far, only a few IL studies and research in Singapore secondary schools had been reported. For example, in 1998, the MOE collaborated with the then National Library Board Institute (NLBI) to conduct training programs for the Heads of Department for Information Technology and Media Resource Library (HOD IT/MRL) from the high schools. ${ }^{7} \mathrm{~A}$ year later, the MOE and the National Library Board (NLB) organized the Library@School Conference in September 1999 with the specific objective of helping schools enhance their libraries and extend their services to both students and teachers in the schools. ${ }^{8}$ This study is the first to acquire data about Singapore tertiary students' skills in searching, evaluating, and using information. A comprehensive instrument encompassing the basic IL skills, as well as a new dimension of ethical usage of information and collaborative information seeking was developed and used for data collection.

\section{LITERATURE REVIEW}

This section reviews the literature on IL in terms of definition, standards and guidelines, education, and assessment.

\section{Definition of Information Literacy}

The term "information literacy" (IL) was coined by Paul Zurkowski in the 1970s to bring attention to the needs of people working in emerging technological environments. ${ }^{9}$ Since then, the concept has been mainly used by information specialists, and promulgated worldwide through the work of the American Library Association (ALA) and the National Forum for Information Literacy. ${ }^{10}$ However, there is no agreed definition of the term. Some researchers describe IL as requisites to lifelong learning, ${ }^{11}$ while others perceive it as a natural extension of the concept of literacy in our society. ${ }^{12}$ Some have associated IL with information technology, ${ }^{13}$ while others have used it interchangeably with library skills. ${ }^{14}$

The 1989 Final Report of the American Library Association's Presidential Committee on Information Literacy, as a milestone in the history of IL research, not only recognised the importance of IL skills, but also sought to define the term. ${ }^{15}$ This definition was widely accepted: to be information literate, a person must be able to recognise the need for information, and to effectively access, evaluate, and creatively use information. Todd defined IL as "a holistic, interactive learning process encompassing the skills of defining, locating, selecting, organising, presenting, and evaluating information." ${ }^{16}$ Goad gave a brief definition as "the ability to search for, find, evaluate, and use information from a variety of sources." 17

In the twenty-first century, IL requires a move beyond a skills-based approach, especially in response to technological innovations such as the Internet and should focus on the production of knowledge in collaboration with others. ${ }^{18}$ Marcum proposed IL should focus on social and multimodal networked technological environments in line with the proliferation of web technologies. ${ }^{19}$ As a result, current innovative collaborative technologies such as social media environments and online communities have resulted in calls for IL to be redefined as a subfield of metaliteracy or metacompetency. ${ }^{20}$ Metaliteracy is defined as an overarching and self-referential framework that integrates emerging technologies and unifies multiple literacy types, which encompasses IL and other interrelated concepts including media literacy, digital literacy, visual literacy, cyberliteracy, and information fluency. ${ }^{21}$ It is without a doubt that IL is central to this redefinition because information takes many forms online and is produced and communicated through multiple modalities.

Critical IL is an emerging discipline for IL instruction. Based on a review of Accardi, Drabinski, and Kumbier's book Critical Library Instruction: Theories and Methods, Kershner pointed out that current trends in IL instruction display two main themes: the first is the "one-shot" session that still remains the preferred format, and the second is the growing interest in assessment for measuring the outcomes. ${ }^{22}$ Using the critical literacy theory to define IL, Elmborg argued that literacy educators must focus less on information transfer and more on developing critical consciousness in students. ${ }^{23}$ In another words, IL instructors must stop teaching "library-as-subject," and instead specialize in coaching critical development and intellectual growth.

\section{Information Literacy Standards and Guidelines}

The landmark publication "Information Power: Building Partnerships for Learning" produced by American Association of School Librarians (AASL) and Association for Educational Communications and Technology (AECT) subsequently became the basis for IL standards and guidelines in numerous educational institutions across several countries. ${ }^{24}$ The Association of College and Research Libraries (ACRL) expanded on the standards and guidelines given in the AASL publication and produced its "Information Literacy Standards for Higher Education." 25

Moving away from the United States, the Council of Australian University Librarians (CAUL) adopted the ACRL standards, modified them, and developed their own "Information Literacy Standards" for use primarily in higher education although they are applicable to other educational levels. ${ }^{26}$ The standards were revised in 2003 and renamed as the "Australian and New Zealand Information Literacy Framework." Similarly, the Society of College, National and University 


\section{FEATURE}

Libraries (SCONUL) in the United Kingdom presented their position paper on "Information skills in higher education."27 The paper proposed the "Seven Pillars Model" based on seven skill sets that stemmed from a basic competence in library and information technology skills.

In Singapore, more than a decade ago, the School Libraries Unit of the MOE's Curriculum Planning and Development Division (CPDD) prepared and published the Information Literacy Guidelines (ILG) and Information Literacy Supplementary Materials (ILSM) for use in Singapore schools from the elementary through preuniversity level. ${ }^{28}$ Using the aforementioned standards as a guide, a group of researchers from Nanyang Technological University proposed a $6+3$ model to help develop IL standards for schools in Singapore. ${ }^{29}$

\section{Information Literacy Assessment}

With the emergence of standards, comes the need for assessment, a way to measure performance against the standards. The objectives for assessing IL usually include: to increase student learning, to provide accountability, and/ or to strengthen instructional programs. ${ }^{30}$

Oakleaf identified three major assessment approaches, fixed-choice test, performance assessment, and rubrics. ${ }^{31}$ Comparatively, fixed-choice test is easier to implement and widely adopted for assessing IL skills, as it is less resourcesintensive, and the results can be used for comparison at different levels from individual to institutional. Examples include standardized IL tests such as Standardized Assessment of Information Literacy Skills (SAILS), Tool for RealTime Assessment of Information Literacy (TRAILS) and Research Readiness Self-Assessment (RRSA) assessing discrete IL skills. ${ }^{32}$ These standardized tests allow efficient testing of large number of students and they can be easily adapted for use at other institutions.

Performance assessment, which includes methods such as bibliographic assessment, observation of student behaviour and simulation, tests higher level skills but it is more resource intensive. ${ }^{33}$ This approach increases the relevance of IL instruction and uses authentic assessment. The third approach, rubrics, involves using a set of descriptive scoring schemes to evaluate students' work, which allows measurement of higher-order thinking and enables students to understand the expectation of their instructors. ${ }^{34}$ Rubrics are suitable for IL instruction that is integrated into other subject curriculum, as its flexibility allows easy transfer to any discipline or learning environment. ${ }^{35}$

However, in the recent years, results derived from the various IL assessments across the world were unsatisfactory. Students appear to have strong reliance on Internet search engines for acquiring information. ${ }^{36}$ Internet search engines may help retrieve overwhelming number of results efficiently, however, unlike academic resources as electronic databases and journals, the retrieved information may not be always reliable and accurate. Relying heavily or merely on web sources may result in the potential spread of misinformation and disinformation. Moreover, only a small portion of students would be able to formulate proper search strategy using Boolean operators, assess the credibility of a source, and differentiate citations and reference sources. ${ }^{37}$ According to a study conducted in the UK and the US, only half of the faculty members felt that the graduated students had all the seven IL skills highlighted in the SCONUL assessment. ${ }^{38}$ Against this background, this study attempts to assess the IL skills of Singapore tertiary students.

\section{METHOD}

Data for this study was collected through a questionnaire survey. The questionnaire was developed by a team comprising Information Studies and Education faculty members of Nanyang Technological University (NTU). Some instruments used by previous studies were consulted (e.g. SAILS, TRAILS), and the survey contents were contextualized and made relevant to students in Singapore.

The questionnaire was divided into two sections. Section 1 had 14 questions collecting demographic information about the participants such as gender, age, education background, Internet access, and use frequency of various libraries. Section 2 comprised 30 multiple-choice questions to test IL skills covered by Eisenberg and Berkowitz's Big6 model, including task definition, information seeking strategies, location and access, information use, information synthesis, and information evaluation. ${ }^{39}$ The recent work on information ethics (awareness of censorship) and collaborative information seeking aspects were also included in the questionnaire as proposed by the $6+3$ model. ${ }^{40}$

Questions for testing IL skills were weighted differently according to their perceived difficulty levels. The majority of questions had only one correct answer. Students who answered correctly received the full mark for that question. There were also seven questions with more than one correct answer. For this kind of question, the best answer was assigned a higher mark while the 2nd (and 3rd) best answer(s) was/were allocated lower marks. For example, a question inquired about the authoritative reference resource to be used to find out which football team won the World Cup in 1970. Three points were allocated to the best answer "almanac" while one point was given to the answer "encyclopaedia."

To validate the instrument, it was sent to a number of IL experts from Hong Kong, Kuwait, and Thailand for assessment and comments, as well as being subsequently pretested with a group of students in Singapore. Some improvements were made to the questionnaire based on the feedback received. For example, some long and complex questions were modified or removed, and simple language was used in the survey to minimize the influence of students' reading and comprehension skills.

The data was collected through SurveyMonkey, an online survey platform. In early October 2011, an invitation letter stating the purpose of the survey was sent to all 
Table 1. Respondents from Each School

\begin{tabular}{l|ccccc|c|c}
\hline & \multicolumn{3}{c|}{ Respondents } & & \\
School & Year 1 & Year 2 & Year 3 & Year 4 & Total & Total Students & Response Rate \\
ADM & 10 & 12 & 8 & 4 & 34 & 670 & $5.07 \%$ \\
HSS & 127 & 83 & 82 & 93 & 385 & 2,483 & $15.51 \%$ \\
WKWSCI & 26 & 25 & 23 & 41 & 115 & 673 & $17.09 \%$ \\
\hline Total & 163 & 120 & 113 & 138 & 534 & 3,826 & $13.96 \%$ \\
\hline
\end{tabular}

undergraduate students $(3,826$ in total) from the College of Humanities, Arts, and Social Sciences, Nanyang Technological University, Singapore. At the end of the four-week data collection period that included one email reminder, a total of 534 students had completed the survey, representing a response rate at 13.96 percent. The survey data was analysed using Statistical Package for the Social Sciences (SPSS) 16.0.

\section{ANALYSIS RESULTS}

\section{Students' Profile}

The College of Humanities, Arts, and Social Sciences (HASS) comprises three schools in Nanyang Technological University, namely, School of Arts, Design, and Media (ADM), School of Humanities and Social Sciences (HSS), and Wee Kim Wee School of Communication and Information (WKWSCI). The number and percentage of respondents from each school is shown in table 1.

Among the 534 responding students, the majority (525 or 98.31 percent) were born between 1986 and 1992, and 126 (23.6 percent) were male while 408 (76.4 percent) were female. Some 489 (91.6 percent) of the respondents received their pretertiary education in Singapore. The majority of students (531 or 99.4 percent) own a personal computer, and nearly all of them (except 1 student) have Internet access at their place of residence. Only 90 (16.9 percent) of the students had taken the course related to IL. The respondents' year of study was shown in figure 1 .

Students were asked their frequency of visiting and using resources in various libraries respectively. The results are shown in tables 2 and 3. It was not surprising to find that students tended to visit and use resources in university library more frequently as compared to the other libraries. For each kind of library, the frequency of using resources was slightly less than visiting. It is possible that some students study in the library without consulting its information resources.

\section{Test of Information Literacy Skills}

All six aspects of IL skills covered by the Big6 model were tested through multiple-choice questions. As mentioned earlier, the questions were weighted differently according

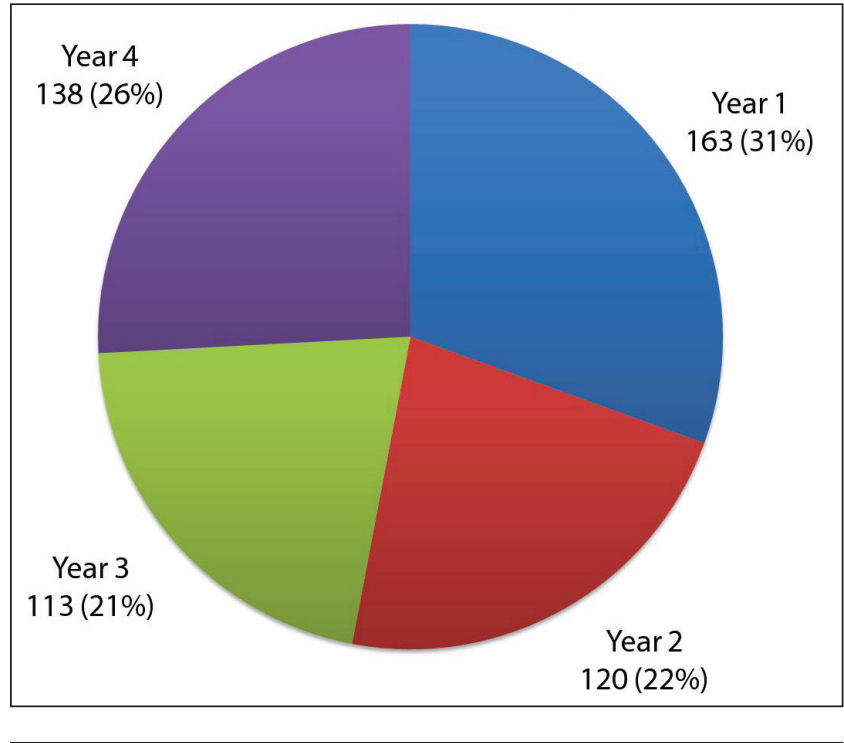

Figure 1. Respondents'Year of Study

to their difficulty levels, and some questions had more than one correct answer. The scores are normalized to 100 percent for each category and as a whole instrument. Figure 2 shows the spread of the standardized percentage scores among the study population. The majority of students scored between 50 and 80 out of 100. The standardized percentage scores for each aspect of IL are shown in table 4. The scores are moderate at an overall study population level, with a mean score at 64.81/100. "Task Definition" is the best-performing area, whereas "information evaluation" is the poorest-performing area, with the mean score at $50.31 / 100$.

Table 5 lists the standardized mean score for each area of IL skills. The respondents scored above 90/100 for questions about narrowing search results, Boolean operators and stop-words. However, students seemed to lack understanding how to use the index of a book; how to differentiate fact, view, and opinion; and how to select authoritative information sources and information evaluation tools. All these areas registered mean scores between 50 and 100. Respecting intellectual property is an important aspect of information ethics. A question was asked to test students' understanding 


\section{FEATURE}

Table 2. Frequencies of Visiting Various Libraries

\begin{tabular}{|c|c|c|c|c|c|c|}
\hline Library & Daily & $\begin{array}{c}\text { 2-3 Times a } \\
\text { Week }\end{array}$ & Weekly & $\begin{array}{c}\text { 2-3 Times a } \\
\text { Month }\end{array}$ & Rarely & Never \\
\hline University & $42(7.9 \%)$ & $152(28.5 \%)$ & $106(19.9 \%)$ & $130(24.3 \%)$ & $92(17.2 \%)$ & $12(2.2 \%)$ \\
\hline Public & $0(0.0 \%)$ & $11(2.1 \%)$ & $41(7.7 \%)$ & $155(29.0 \%)$ & $260(48.7 \%)$ & 67 (12.5\%) \\
\hline National & $1(0.2 \%)$ & $5(0.9 \%)$ & $23(4.3 \%)$ & $106(19.9 \%)$ & $321(60.1 \%)$ & 78 (14.6\%) \\
\hline Other & $1(0.2 \%)$ & $4(0.7 \%)$ & $5(0.9 \%)$ & $27(5.1 \%)$ & $252(47.2 \%)$ & $245(45.9 \%)$ \\
\hline Library & Daily & $\begin{array}{l}\text { 2-3 times a } \\
\text { Week }\end{array}$ & Weekly & $\begin{array}{l}\text { 2-3 times a } \\
\text { month }\end{array}$ & Rarely & Never \\
\hline University & $38(7.1 \%)$ & $131(24.5 \%)$ & $94(17.6 \%)$ & $123(23.0 \%)$ & $114(21.3 \%)$ & $34(6.4 \%)$ \\
\hline Public & $2(0.4 \%)$ & $9(1.7 \%)$ & $29(5.4 \%)$ & $120(22.5 \%)$ & $266(49.8 \%)$ & $108(20.2 \%)$ \\
\hline National & $0(0.0 \%)$ & $5(0.9 \%)$ & $17(3.2 \%)$ & $102(19.1 \%)$ & $292(54.7 \%)$ & $118(22.1 \%)$ \\
\hline Other & $0(0.0 \%)$ & $4(0.7 \%)$ & $4(0.7 \%)$ & $27(5.1 \%)$ & $229(42.9 \%)$ & $270(50.6 \%)$ \\
\hline
\end{tabular}

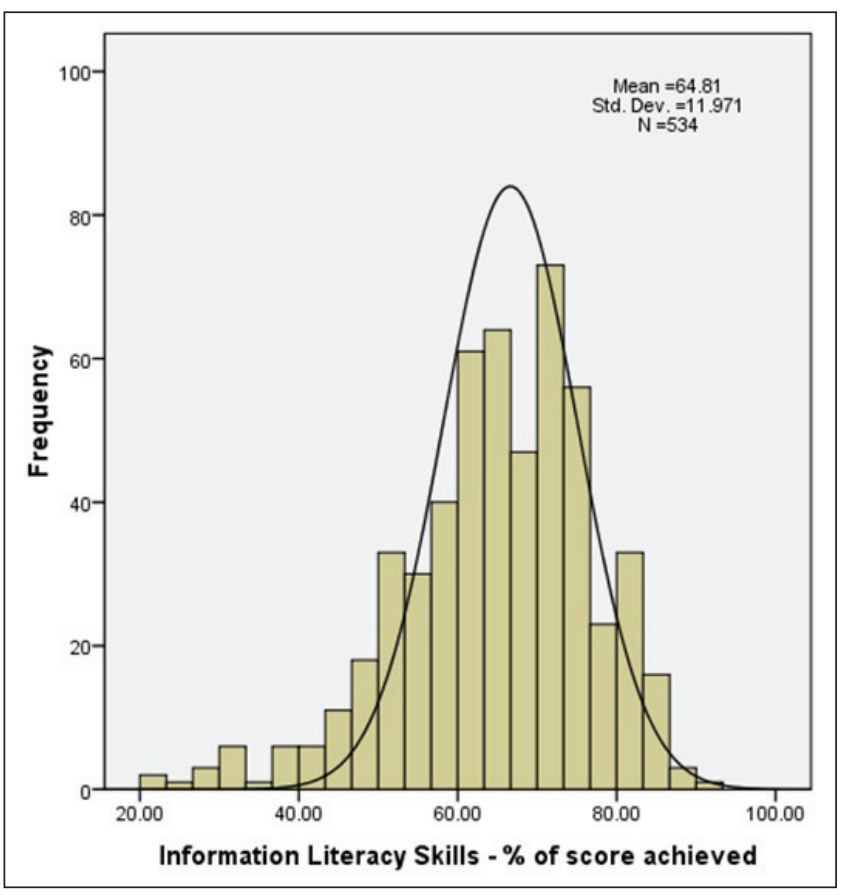

Figure 2. Histogram of Standardized Percentage Score for IL Skills

of copyright, which appeared to be a serious issue with the mean score of $15.17 / 100$.

Male students were found to score slightly higher than female students (65.02 vs. 64.74). Students receiving pretertiary education in Singapore scored higher than those coming from overseas (65.44 vs. 57.76), and the difference was found to be significant (significance $=0.000$ ) through t-test. Further analysis detected significant differences for "information seeking," "location \& access," "information use," and "information
Table 4. Standardized Percentage Score for Each IL Skill

\begin{tabular}{|c|c|c|c|c|}
\hline & Mean & Min & Max & SD \\
\hline Task Definition & 80.41 & 0.00 & 100.00 & 26.67 \\
\hline $\begin{array}{l}\text { Information } \\
\text { Seeking Strategies }\end{array}$ & 65.58 & 0.00 & 100.00 & 21.32 \\
\hline Location \& Access & 69.12 & 12.82 & 100.00 & 16.89 \\
\hline Information Use & 59.70 & 0.00 & 100.00 & 20.74 \\
\hline $\begin{array}{l}\text { Information } \\
\text { Synthesis }\end{array}$ & 59.05 & 0.00 & 100.00 & 36.70 \\
\hline $\begin{array}{l}\text { Information } \\
\text { Evaluation }\end{array}$ & 50.31 & 0.00 & 100.00 & 20.82 \\
\hline
\end{tabular}

synthesis" at the 0.05 level (table 6).

As expected, students who had taken the IL related course before scored higher than the rest of students (70.78 vs. 63.58), and the difference was also found to be significant (significance $=0.000$ ) . Further analysis showed "information seeking," "location \& access," "information synthesis," and "information evaluation" contribute significantly to the difference at the 0.01 level (table 7).

It was not surprising to find that there was an improvement of scores with the year of study, with higher level students performing better than the lower level students in the university (figure 3). Further comparison showed that higher scores were attributed to areas of "information seeking," "location \& access" and "information synthesis" (figure 4). This is easily understandable as senior students, studying higher level subjects with higher levels of difficult and demand, are more experienced information seekers, for they tend to be more engaged in information-intensive activities, such as 
Table 5. Standardized Mean Score for each Testing Area of IL Skills

\begin{tabular}{|c|c|c|c|}
\hline IL Skill & $\begin{array}{c}\text { No. of } \\
\text { Questions }\end{array}$ & IL Test Areas & Mean (Max 100) \\
\hline \multirow[t]{2}{*}{ Task Definition } & \multirow[t]{2}{*}{2} & Brainstorming/Defining task & 74.34 \\
\hline & & Research topics \& questions & 86.47 \\
\hline \multirow[t]{4}{*}{ Information Seeking Strategies } & \multirow[t]{4}{*}{4} & Seeking expert opinion & 70.79 \\
\hline & & Primary vs. secondary information sources & 75.09 \\
\hline & & Appropriate sources of information & 76.59 \\
\hline & & Reference resources & 51.12 \\
\hline \multirow[t]{11}{*}{ Location \& Access } & \multirow[t]{11}{*}{11} & Organization of call numbers & 71.86 \\
\hline & & Roles of reference librarians & 73.41 \\
\hline & & OPAC & 63.30 \\
\hline & & Using index of a book & 41.25 \\
\hline & & Narrowing search results* & 94.76 \\
\hline & & Boolean operators* & 96.07 \\
\hline & & Broadening searches & 66.29 \\
\hline & & Stop-words* & 95.32 \\
\hline & & Search fields & 89.89 \\
\hline & & Phrase search & 66.85 \\
\hline & & Truncation & 53.37 \\
\hline \multirow[t]{5}{*}{ Information Use } & \multirow[t]{5}{*}{5} & Evaluating information content & 77.90 \\
\hline & & Cross-comparison of content & 77.46 \\
\hline & & Critical assessment of information & 81.84 \\
\hline & & Fact, view, or opinion? & 32.21 \\
\hline & & Authoritative information source & 46.82 \\
\hline Information Synthesis & 2 & Citation Style & 54.87 \\
\hline \multirow[t]{3}{*}{ Information Evaluation } & \multirow[t]{3}{*}{3} & Information evaluation tools/resources & 49.06 \\
\hline & & Plagiarism & 86.70 \\
\hline & & Copyright & 15.17 \\
\hline
\end{tabular}

Note: The highlighted rows show areas where the mean score is less than or equal to 50/100. Asterisks indicate scores greater than 90/100.

Table 6. Comparison of Standardized Mean Percentage Scores for each IL Skill between Students Receiving and Not Receiving PreTertiary Education in Singapore

\begin{tabular}{lcccccc}
\hline & Task Definition & $\begin{array}{c}\text { Information } \\
\text { Seeking }\end{array}$ & $\begin{array}{c}\text { Location \& } \\
\text { Access }\end{array}$ & $\begin{array}{c}\text { Information } \\
\text { Use }\end{array}$ & $\begin{array}{c}\text { Information } \\
\text { Synthesis }\end{array}$ & $\begin{array}{c}\text { Information } \\
\text { Evaluation }\end{array}$ \\
Yes $(\mathbf{N}=\mathbf{4 8 9})$ & 80.8282 & 66.7306 & 69.8152 & 60.3272 & 60.0545 & 50.1363 \\
\hline No $(\mathbf{N}=\mathbf{4 5})$ & 75.8333 & 53.0556 & 61.5385 & 52.8655 & 48.1481 & 52.2222 \\
Sig. & 0.267 & 0.000 & 0.001 & 0.035 & 0.038 & 0.474 \\
\hline
\end{tabular}

assignments, final year project, and job hunting.

Figure 5 shows the standardized mean percentage score across the three participating schools. It was found that students from WKWSCI scored higher than the other two schools. This result was expected as IL had been integrated as a compulsory course into their curriculum for these students.
It is also possible that these are brighter students as the academic requirement for students admitted to WKWSCI are the highest among the schools in the college.

Figure 6 presents the comparisons of mean scores for each IL skill across the three schools. It was found that the scores for "information synthesis" showed the greatest difference, 


\section{FEATURE}

Table 7. Comparison of Standardized Mean Percentage Scores for each IL Skill between Students Attending and Not Attending the IL Course

\begin{tabular}{lcccccc}
\hline & Task Definition & $\begin{array}{c}\text { Information } \\
\text { Seeking }\end{array}$ & $\begin{array}{c}\text { Location } \& \\
\text { Access }\end{array}$ & $\begin{array}{c}\text { Information } \\
\text { Use }\end{array}$ & $\begin{array}{c}\text { Information } \\
\text { Synthesis }\end{array}$ & $\begin{array}{c}\text { Information } \\
\text { Evaluation }\end{array}$ \\
Yes $(\mathbf{N}=\mathbf{9 0})$ & 83.1944 & 74.0972 & 77.1510 & 60.1754 & 67.7778 & 55.7407 \\
\hline No $(\mathbf{N}=\mathbf{4 4 4 )}$ & 79.8423 & 63.8514 & 67.4893 & 59.6017 & 57.2823 & 49.2117 \\
Sig. & 0.2610 & 0.0000 & 0.0000 & 0.7930 & 0.0100 & 0.0080 \\
\hline
\end{tabular}

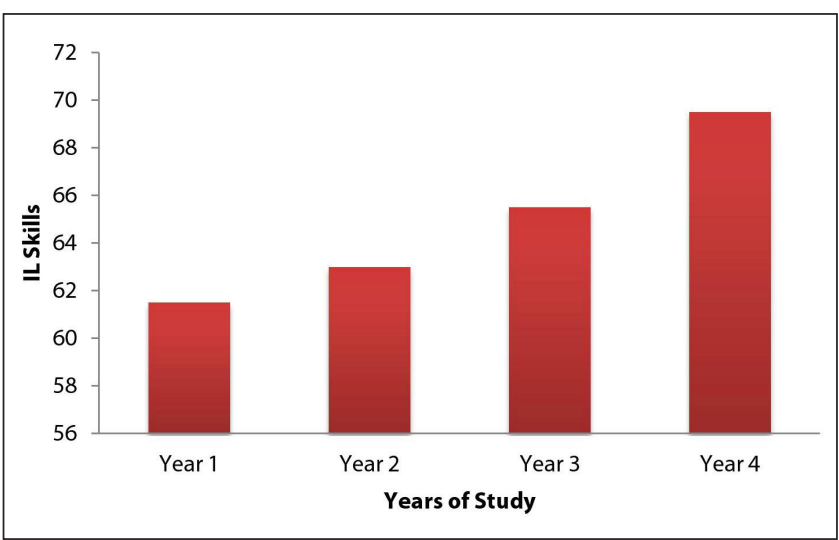

Figure 3. Standardized Mean Percentage Scores for IL Skills across Years of Study

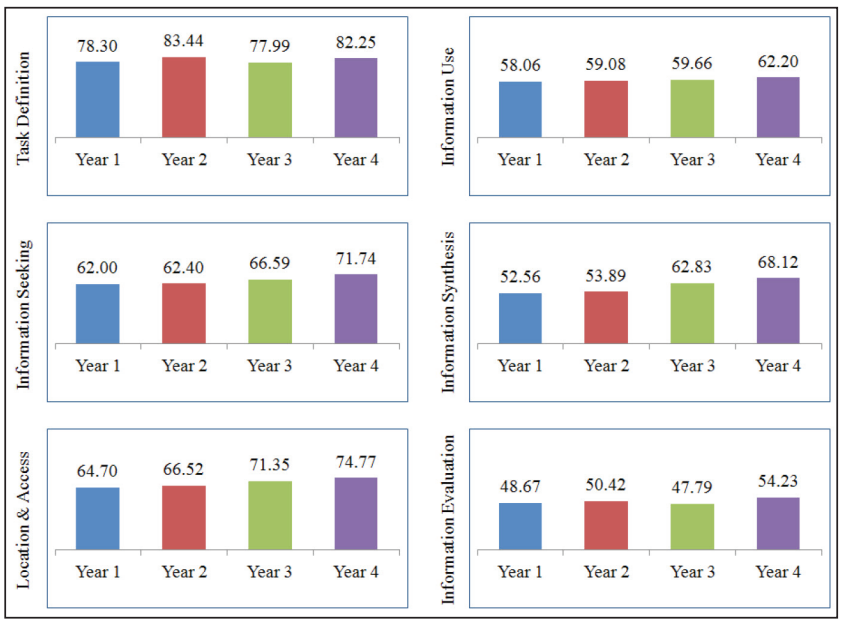

Figure 4. Standardized Mean Percentage Scores for each IL Skill across Years of Study

with WKWSCI having the highest score percentage of 67.54 and ADM having the lowest score percentage of 47.06. This is probably due to the higher requirement in synthesizing information for students majoring in communication studies, especially for those specializing in journalism and communication research.

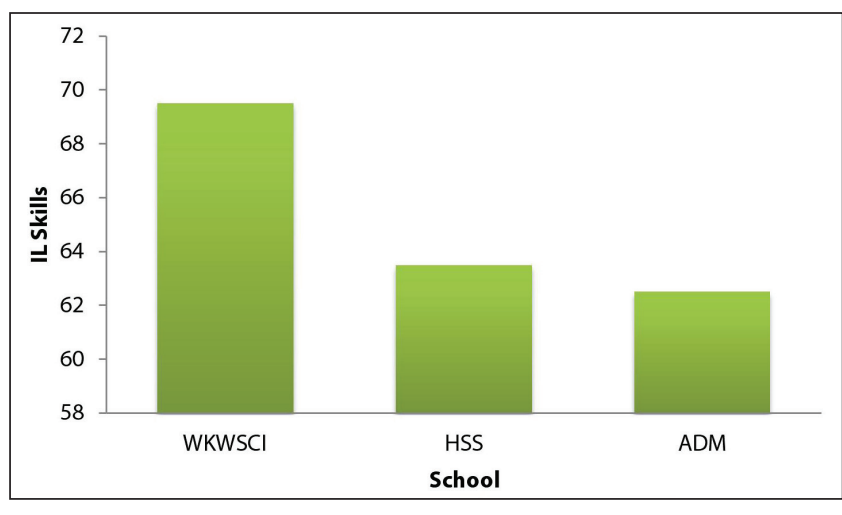

Figure 5. Standardized Mean Percentage Scores for IL Skills across Schools

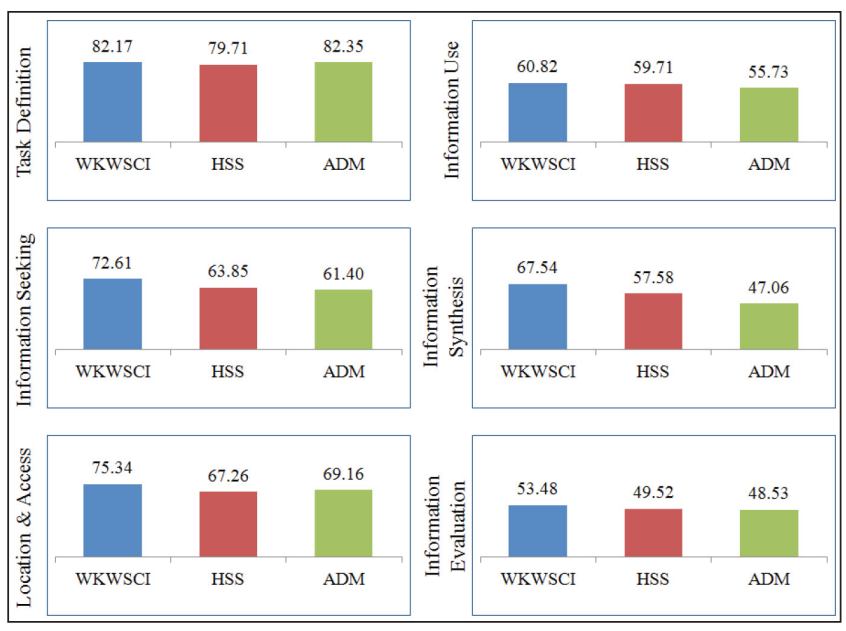

Figure 6. Standardized Mean Percentage Scores for Each IL Skill across Schools

\section{INFORMATION ETHICS AND COLLABORATIVE INFORMATION SEEKING}

Two questions were asked to respectively test students' knowledge about information ethics (awareness of censorship) and collaborative information seeking. The standardized mean percentage scores for the three schools and the study population are shown in table 8 . Similar to the results 
for the IL skills test, students from WKWSCI scored higher than those from the other two schools.

Other findings show that students receiving pretertiary education in Singapore had much higher awareness of censorship as compared to those who did their pretertiary education overseas (77.30 vs. 33.33). They also had a better understanding of collaborative information seeking (82.00 vs. 66.67). "Whether having taken the IL course before" was found to have significant impact on students' awareness of censorship ( 87.78 vs. 70.72 , significance $=0.001$ ), but not on collaborative information seeking (82.22 vs. 80.40 ).

The final survey question asked students whether they would consult several potential human information sources for complete the information tasks covered by the Big6 model. It was found that for "defining the research topic and scope," more students would consult professors, followed by peers (classmates). While for the other five information tasks, more students tended to discuss with their peers (classmates) followed by professors and friends (table 9).

It was a matter of concern that a considerable percentage (above 20 percent) of students did not consult anyone for "identifying potential sources of relevant information" and "formulating search strategy, statement and retrieving information," although their mean scores in these fields were below 70/100.

\section{DISCUSSION}

The majority of students reported that they visited university libraries at least 2 to 3 times a month, with more than 20 percent of them going and using resources there 2 to 3 times a week. This can probably be attributed to the success of NTU libraries in providing a rich set of relevant academic

Table 8. Standardized Mean Percentage Scores for Awareness of Censorship and Collaborative Information Seeking

\begin{tabular}{lcccc}
\hline & WKWSC & HSS & ADM & $\begin{array}{c}\text { Study } \\
\text { Population }\end{array}$ \\
Awareness of Censorship & 91.30 & 69.35 & 61.76 & 73.60 \\
Collaborative Information Seeking & 85.22 & 79.22 & 82.35 & 80.71 \\
\hline
\end{tabular}

Table 9. Consultation of Human Information Sources for Completing Information Tasks

\begin{tabular}{|c|c|c|c|c|c|c|c|}
\hline Information Task & $\begin{array}{c}\text { Peers } \\
\text { (Classmates) }\end{array}$ & Friends & ct All that A & Librarians & $\begin{array}{l}\text { Others with } \\
\text { Common } \\
\text { Interest }\end{array}$ & $\begin{array}{l}\text { I Don't } \\
\text { Consult } \\
\text { Anyone }\end{array}$ & $\begin{array}{l}\text { I Don't Do } \\
\text { This Task }\end{array}$ \\
\hline $\begin{array}{l}\text { Define the research } \\
\text { topic \& scope }\end{array}$ & $\begin{array}{c}289 \\
(54.1 \%)\end{array}$ & $\begin{array}{c}173 \\
(32.4 \%)\end{array}$ & $\begin{array}{c}378 \\
(70.8 \%)\end{array}$ & $\begin{array}{c}23 \\
(4.3 \%)\end{array}$ & $\begin{array}{c}60 \\
(11.2 \%)\end{array}$ & $\begin{array}{c}69 \\
(12.9 \%)\end{array}$ & $\begin{array}{c}4 \\
(0.7 \%)\end{array}$ \\
\hline $\begin{array}{l}\text { Identify potential } \\
\text { sources of relevant } \\
\text { information }\end{array}$ & $\begin{array}{c}301 \\
(56.4 \%)\end{array}$ & $\begin{array}{c}202 \\
(37.8 \%)\end{array}$ & $\begin{array}{c}212 \\
(39.7 \%)\end{array}$ & $\begin{array}{c}144 \\
(27.0 \%)\end{array}$ & $\begin{array}{c}99 \\
(18.5 \%)\end{array}$ & $\begin{array}{c}111 \\
(20.8 \%)\end{array}$ & $\begin{array}{c}4 \\
(0.7 \%)\end{array}$ \\
\hline $\begin{array}{l}\text { Formulate search } \\
\text { strategy statements } \& \\
\text { retrieve information }\end{array}$ & $\begin{array}{c}261 \\
(48.9 \%)\end{array}$ & $\begin{array}{c}171 \\
(32.0 \%)\end{array}$ & $\begin{array}{c}160 \\
(30.0 \%)\end{array}$ & $\begin{array}{c}85 \\
(15.9 \%)\end{array}$ & $\begin{array}{c}51 \\
(9.6 \%)\end{array}$ & $\begin{array}{c}149 \\
(27.9 \%)\end{array}$ & $\begin{array}{c}20 \\
(3.7 \%)\end{array}$ \\
\hline $\begin{array}{l}\text { Analyze quality } \\
\text { of retrieved } \\
\text { information \& select } \\
\text { relevant information } \\
\text { for use }\end{array}$ & $\begin{array}{c}300 \\
(56.2 \%)\end{array}$ & $\begin{array}{c}181 \\
(33.9 \%)\end{array}$ & $\begin{array}{c}274 \\
(51.3 \%)\end{array}$ & $\begin{array}{c}67 \\
(12.5 \%)\end{array}$ & $\begin{array}{c}88 \\
(16.5 \%)\end{array}$ & $\begin{array}{c}100 \\
(18.7 \%)\end{array}$ & $\begin{array}{c}9 \\
(1.7 \%)\end{array}$ \\
\hline $\begin{array}{l}\text { Organize, compile, } \\
\text { finalize \& present } \\
\text { answer to research } \\
\text { topic }\end{array}$ & $\begin{array}{c}342 \\
(64.0 \%)\end{array}$ & $\begin{array}{c}215 \\
(40.3 \%)\end{array}$ & $\begin{array}{c}243 \\
(45.5 \%)\end{array}$ & $\begin{array}{c}18 \\
(3.4 \%)\end{array}$ & $\begin{array}{c}54 \\
(10.1 \%)\end{array}$ & $\begin{array}{c}94 \\
(17.6 \%)\end{array}$ & $\begin{array}{c}5 \\
(0.9 \%)\end{array}$ \\
\hline $\begin{array}{l}\text { Evaluate the } \\
\text { completed product } \\
\& \text { process of } \\
\text { information seeking }\end{array}$ & $\begin{array}{c}293 \\
(54.9 \%)\end{array}$ & $\begin{array}{c}203 \\
(38.0 \%)\end{array}$ & $\begin{array}{c}276 \\
(51.7 \%)\end{array}$ & $\begin{array}{c}27 \\
(5.1 \%)\end{array}$ & $\begin{array}{c}60 \\
(11.2 \%)\end{array}$ & $\begin{array}{c}82 \\
(3.4 \%)\end{array}$ & $\begin{array}{c}18 \\
(3.4 \%)\end{array}$ \\
\hline
\end{tabular}




\section{FEATURE}

resources and facilities for study and research in a conducive and comfortable environment. In contrast, a large portion of these students rarely went to the public, national, and other libraries. As the bulk of their visits are made to the NTU libraries where their needs are met, there may be little or no reason to visit these other libraries whose collections and environments are designed to cater for other and different groups of library users.

The study found that students scored higher in areas related to "task definition," "information seeking strategy," and "location and access." These are skills that can be taught more systematically, for example in LIS instructional programs offered by libraries, or acquired over time through practice in completing their academic assignments and project work. The scores attained for areas of "information use," "information synthesis," and "information evaluation" were found to be relatively unsatisfactory. These may be attributed to higher order thinking skills needed to differentiate the quality and relevance of the retrieved information, and to subsequently synthesize, extract, and connect bits of information for use to complete their tasks. This may suggest that more elaborate efforts and the right forms of pedagogy, possibly including mentoring, need to be in place to transmit such skills to students over time.

It was encouraging to find that students receiving pretertiary education in Singapore scored significantly higher than those coming from overseas. "Information seeking," "location $\&$ access," "information use," and "information synthesis" were identified as the major sources of the differences. This probably suggests that Singapore's pretertiary education with remaining traces of IL education in the curriculum has resulted in more information literate students in comparison to those students who have been educated abroad in countries such as China, Indonesia, India, and Malaysia.

Students receiving pretertiary education in Singapore were also found to have higher awareness of censorship. This could be due to the related education received from their parents and teachers, as well as the public awareness created by government and society. This group of students were also found to have a better understanding of collaborative information seeking, which is probably due to their familiarity toward team-based project work that is advocated in the Singapore pretertiary education system.

As expected, students who had taken the IL related course before scored higher than those had not. Previous studies also found that the amount of relevant education had significant correlation with students' IL skills. ${ }^{41}$ Students who had undergone official training in IL could recognize and find information easily as compared to those lack of IL training. ${ }^{42}$ Significant differences were detected for "information seeking," "location \& access," "information synthesis," and "information evaluation," but not for "task definition" or "information use." More attention could be placed on training in these two areas to improve the overall IL competencies of students.
The study also found that senior students scored higher than their junior counterparts. Students from WKWSCI with higher academic entry requirements attained higher mean score than those from HSS and ADM. Gender was not found to be a significant factor influencing the IL skills in this study. This was also observed in another unrelated study by Adetoro, Simisaye, and Oyefuga. ${ }^{43}$

\section{CONCLUSION}

An IL assessment instrument was carefully developed through reference to existing IL standards, guidelines, frameworks, and existing instruments to assess the IL skills of tertiary students in Singapore. The findings from the 534 respondents in the College of Humanities, Arts, and Social Sciences show moderate IL skills scores with room for improvement especially in higher-level skills related to information use, synthesis, and evaluation. Students receiving pretertiary education in Singapore scored higher than those from overseas, which, to some extent, shows that IL education in Singapore is still more effective than that in some other countries. The IL course offered in the university was found to be useful and help lead to higher IL assessment scores. Areas in "task definition" and "information use" are areas in the course can be further strengthened.

Future studies should try to systematically investigate the various ways of incorporating higher order IL skills into the school curriculum. There is also a need to investigate how IL skills may affect the individual's well-being in participating in a democratic society, beyond academic achievements. Moreover, public and national libraries may want to put more efforts to increase tertiary students' awareness to use their resources and facilities as a supplementary to their university libraries.

\section{References}

1. Patricia S. Breivik, "Putting Libraries Back in the Information Society," American Libraries and the Academy 16, no. 10 (1985): 723; Susan Hubbard, "Information Skills for an Information Society: A Review of Research," in Eric Digest (Syracuse, NY: ERIC Clearinghouse on Information Resources, 1987).

2. Patricia S. Breivik and J. A. Senn, "Information Literacy: Partnerships for Power," Emergency Librarian 21, no. 1 (1993): 25-27.

3. Maryam Derakhshan, and Diljit Singh, "Integration of Information Literacy into the Curriculum: A Meta-Synthesis," Library Review 60, no. 3 (2011): 218-29; Yu-Mei Wang, "Riding to the FutureAn Investigation of Information Literacy Skills of Students at an Urban University as Applied to the Web Environment," International Journal on E-Learning 6, no. 4 (2007): 593-603.

4. A South African example is Michiel Moll, "Information Literacy in the New Curriculum," South African Journal of Library \& Information Science 75, no. 1 (2009): 40-45. A Canadian example is Tamsin Bolton, Tina Pugliese, and Jill Singleton-Jackson, "Advancing the Promotion of Information Literacy through Peer-Led Learning," Communications in Information Literacy 3, no. 1 (2009): 20-30. A US example is Mona Anne Niedbala, and Jay Fogleman, 
"Taking Library 2.0 to the Next Level: Using a Course Wiki for Teaching Information Literacy to Honors Students," Journal of Library Administration 50 (2010): 867-82.

5. Singapore Ministry of Education, Information Literacy Guidelines (Singapore: School Libraries Unit, Languages and Library Branch, Curriculum Planning and Development Division, Ministry of Education, 1997); Singapore Ministry of Education, Information Literacy: Supplementary Materials (Singapore: School Libraries Unit, Languages and Library Branch, Curriculum Planning and Development Division, Ministry of Education, 1997).

6. Singapore Ministry of Education, "MOE to Enhance Learning of Twenty-First Century Competencies and Strengthen Art, Music and Physical Education," 2010, accessed February 10, 2012, www.moe.gov.sg/media/press/2010/03/moe-to-enhance-learning -of-21s.php.

7. Singapore National Institute of Education, "Te21: A Teacher Education Model for the Twenty-First Century-A Report by the National Institute of Education" (Singapore: National Institute of Education, 2009).

8. Singapore Ministry of Education, Library@School Conference, 1999, accessed February 20, 2012, www.moe.gov.sg/media/ press/1999/pr990923.htm.

9. Cushla Kapitzke, "Information Literacy: A Positivist Epistemology and a Politics of Outformation," Educational Theory 53, no. 1 (2003): 37-53.

10. John Feather and Paul Sturges, International Encyclopedia of Information and Library Science (London: Routledge, 2003).

11. Penny Moore, "An Analysis of Information Literacy Education Worldwide," white paper prepared for UNESCO, the US National Commission on Libraries and Information Science, and the National Forum on Information Literacy, for use at the Information Literacy Meeting of Experts, 2002, accessed February 2, 2012, http://portal.unesco.org/ci/en/files/19633/11228857221Inf ormation_Literacy_Education_(Moore).pdf/Information\%2BLiter acy\%2BEducation\%2B(Moore).pdf.

12. Christine Bruce, "Information Literacy as a Catalyst for Educational Change: A Background Paper" (paper presented at Information Literacy Meeting of Experts, Prague, The Czech Republic, 2002).

13. Pru Mitchell, "Online Technology in the Curriculum: A Reality" (paper presented at the ASLA XIV Beyond the Horizon Fremantle, Australia, 1996).

14. Carol Collier Kuhlthau, "Information Skills for an Information Society: A Review of Research," Information Reports \& Bibliographies 19, no. 3 (1990): 14-26.

15. American Library Association, "A Progress Report on Information Literacy: An Update on the American Library Association Presidential Committee on Information Literacy: Final Report," 1989, accessed January 10, 2012, www.ala.org/ala/mgrps/divs/ acrl/publications/whitepapers/presidential.cfm\#opp.

16. Ross J. Todd, L. Lamb, and C. McNicholas, "The Power of Information Literacy: Unity of Education and Resources for the twenty-first century" (paper presented at the Annual Meeting of the International Association of School Librarianship, Belfast, Northern Ireland, United Kingdom, 1992).

17. Tom W. Goad, Information Literacy and Workplace Performance (Westport, CT: Quorum, 2002).

18. Mikael Alexandersson and Louise Limberg, "Constructing Meaning through Information Artefacts," New Review of Information Behaviour Research 4 (2003): 17-30; Anna Lundh Louise Limberg, "Information Practices in Elementary School," Libri 58, no. 2 (2008): 92-101; Christine Pawley, "Information Literacy: A Contradictory Coupling," Library Quarterly 73, no. 4 (2003): 422-52.

19. James W. Marcum, "Rethinking Information Literacy," Library Quarterly 72, no. 1 (2002): 1-26.
20. Annemaree Lloyd, "The Meta-Competency of the Knowledge Economy? An Exploratory Paper," Journal of Librarianship and Information Science 35, no. 2 (2003): 87-91.

21. Thomas P. Mackey and Trudi E. Jacobson, "Reframing Information Literacy as a Metaliteracy," College \& Research Libraries 72, no. 1 (2011): 62-78.

22. Seth Kershner, "Critical Library Instruction: Theories and Methods (2010) (Review)," Library Student Journal, 2011, accessed March 7, 2013, www.librarystudentjournal.org/index.php/lsj/ article/view/198/298.

23. James Elmborg, "Critical Information Literacy: Implications for Instructional Practice," Journal of Academic Librarianship 32, no. 2 (2006), 192-99.

24. American Association of School Librarians (AASL) and Association for Educational Communications and Technology (AECT), "Information Power: Building Partnerships for Learning," 1998, accessed February 20, 2012, www.ala.org/ala/aasl/aaslproftools/ informationpower/InformationLiteracyStandards_final.pdf.

25. Association of College and Research Libraries, "Information Literacy Standards for Higher Education," 2000, accessed February 20, 2012, www.ala.org/ala/acrl/acrlstandards/standards.pdf.

26. Council of Australian University Librarians, "Information Literacy Standards," 2001, accessed February 10, 2012, http://ilp.anu.edu .au/Infolit_standards_2001.html.

27. Society of College, National and University Libraries, "Information Skills in Higher Education," 1999, accessed February 8, 2012, www.sconul.ac.uk/groups/information_literacy/papers/ Seven_pillars2.pdf.

28. Singapore Ministry of Education, Information Literacy.

29. Intan Azura Mokhtar et al., "Proposing a 6+3 Model for Developing Information Literacy Standards for Schools: A Case for Singapore," Education for Information 27, no. 2-3 (2010): 505-21.

30. Megan Oakleaf and Neal Kaske, "Guiding Questions for Assessing Information Literacy in Higher Education," Libraries \& the Academy 9, no. 2 (2009): 273-86.

31. Megan Oakleaf, "Dangers and Opportunities: A Conceptual Map of Information Literacy Assessment Approaches," Libraries \& the Academy 8, no. 3 (2008): 233-53.

32. Debbie Abilock, "Choosing Assessments That Matter," Knowledge Quest 35, no. 5 (2007): 8-12; Barbara F. Schloman and Julie A. Gedeon, "Creating Trails: Tool for Real-Time Assessment of Information Literacy Skills," Knowledge Quest 35, no. 5 (2007): 44-47.

33. Megan Oakleaf, "Dangers and Opportunities," 233-53.

34. Jos van Helvoort, "A Scoring Rubric for Performance Assessment of Information Literacy in Dutch Higher Education," Journal Of Information Literacy 4, no. 1 (2010): 22-39.

35. Carol McCulley, "Mixing and Matching: Assessing Information Literacy," Communications in Information Literacy 3, no. 2 (2009): $171-80$.

36. Nicole Johnston, "Is an Online Learning Module an Effective Way to Develop Information Literacy Skills?" Australian Academic E Research Libraries 41, no. 3 (2010): 207-18; Fiona Salisbury and Sharon Karasmanis, "Are They Ready? Exploring Student Information Literacy Skills in the Transition from Secondary to Tertiary Education," Australian Academic \& Research Libraries 42, no. 1 (2011): 43-58.

37. Judine Ladbrook and Elizabeth Prober, "Information Skills and Critical Literacy: Where Are Our Digikids at with Online Searching and Are Their Teachers Helping?" Australasian Journal of Educational Technology 27, no. 1 (2011): 105-21.

38. Jacqui Weetman DaCosta, "Is There an Information Literacy Skills Gap to Be Bridged? An Examination of Faculty Perceptions and Activities Relating to Information Literacy in the United States and England," College E Research Libraries 71, no. 3 (2010): 203-22.

39. Michael Eisenberg and Rober E. Berkowitz, "Big6 Information 


\section{FEATURE}

Skills," accessed January 30, 2012, http://nb.wsd.wednet.edu/ big6/big6_resources.htm.

40. Intan Azura Mokhtar et al., Education for Information, 505-21.

41. Elizabeth Joy Birmingham et al., "First-Year Writing Teachers, Perceptions of Students' Information Literacy Competencies, and a Call for a Collaborative Approach," Communications in Information Literacy 2, no. 1 (2008): 6-24.

42. George Chipeta, Daisy Jacobs, and Janneke Mostert, "Teaching and Learning of Information Literacy in Some Selected Institu- tions of Higher Learning in Kwazulu-Natal and Malawi," South African Journal of Library \& Information Science 75, no. 1 (2009): $46-57$.

43. Nira Adetoro, A. Simisaye, and A. B. Oyefuga, "Relationship between Perceived Self-Efficacy and Information Literacy among Library and Information Science Undergraduates in a Nigerian University of Education," Ife Psychologia no. 2 (2010), accessed February 1, 2012, http://periodicals.faqs .org/201009/2087472291.html. 